\title{
EVALUATING COSTS OF VEHICLE USE IN MILITARY LOGISTICS
}

\author{
Leon Grašič, Tone Lerher, Bojan Rosi
}

Original scientific paper

The article presents an analytical model of evaluating costs of vehicle use in military logistics adapted to specific construction demands and characteristics of military vehicles, profile (conditions and manner) of use and technological procedures of preventive and remedial maintenance of military vehicles. The proposed model of evaluation enables an equivalent comparison of total costs in advance of use of similar vehicles made by different manufacturers throughout the entire operating period (their service life). Initial (entry) and boundary conditions are clearly defined within the proposed model. The implementation of the analytical model ensures the evaluation and planning of maintenance costs and costs of direct vehicle use in military logistics already at the point of purchasing new vehicles, as well as evaluation of optimal operating period (service life) of vehicles, which leads to increased reliability and availability, and, consequently, to more effective use of military vehicles.

Keywords: analytical model; cost of use; entry and boundary criteria; military vehicles; operating period

Procjena troškova uporabe vozila u vojnoj logistici

Izvorni znanstveni članak

U radu je prikazan analitički model procjene troškova održavanja i uporabe vozila u vojnoj logistici, prilagođen specifičnim konstrukcijskim zahtjevima karakteristikama vojnih vozila, profilu (uvjetima i načinu) uporabe, kao i tehnološkim postupcima preventivnog i korektivnog održavanje vojnih vozila. Predloženi model ocjenjivanja omogućuje unaprijedno ekvivalentnu usporedbu ukupnih troškova uporabe sličnih vozila različitih proizvođača tijekom cijelog vijeka trajanja (to jest kroz cijeli životni vijek ili životni ciklus). U okviru predloženog modela jasno su definirani početni (ulazni) i rubni uvjeti. Implementacija analitičkog modela pruža procjenu i planiranje troškova održavanja i izravnih troškova uporabe vozila u vojnoj logistici već kod kupnje novih vozila, a također i procjenu optimalnoga vijeka trajanja (životnog vijeka) vozila, što vodi do povećanja pouzdanosti i raspoloživosti, a s time i do veće učinkovitost uporabe vojnih vozila.

Ključne riječi: analitički model; troškovi uporabe; ulazni i granični kriteriji; vojna vozila; životni vijek

\section{Introduction}

Military vehicles are expected to be not only extremely robust but also highly reliable, which gives them a high level of availability and, consequently, a high level of operative capability and responsiveness of units using these vehicles. The cost of use of vehicles in military logistics differs greatly from the cost of use of commercial vehicles due to specific conditions and manner of use. Similar to conditions of use, the technological procedures of vehicle maintenance in military logistics also greatly differ from maintenance procedures of commercial vehicles in the civilian sphere. The purpose and manner of use of military vehicles dictates a completely specific approach developing a maintenance strategy, organizing maintenance, performing maintenance planning technological procedures and, last but not least, evaluating maintenance costs.

The graph in Fig. 1 shows the cost of purchasing and using vehicles in military logistics. The basis of purchase is the purchase value including all expenses of the previous stages in the service life: concept (a), development (b) and production (c) costs. Costs of direct use (d) and maintenance (e), including the cost of decommissioning a vehicle (f), must be added to the purchase value of a vehicle and this represents the total price of a vehicle during an operating period (service life). If we compare two different vehicles (Fig. 1, Vehicle A and Vehicle B), a lower purchase value (Vehicle A) in many cases does not always mean the best option if we consider the total cost during its entire operating period. The total cost at the end of the operating period of
Vehicle B is significantly lower than the cost of Vehicle A, despite its higher purchase value.

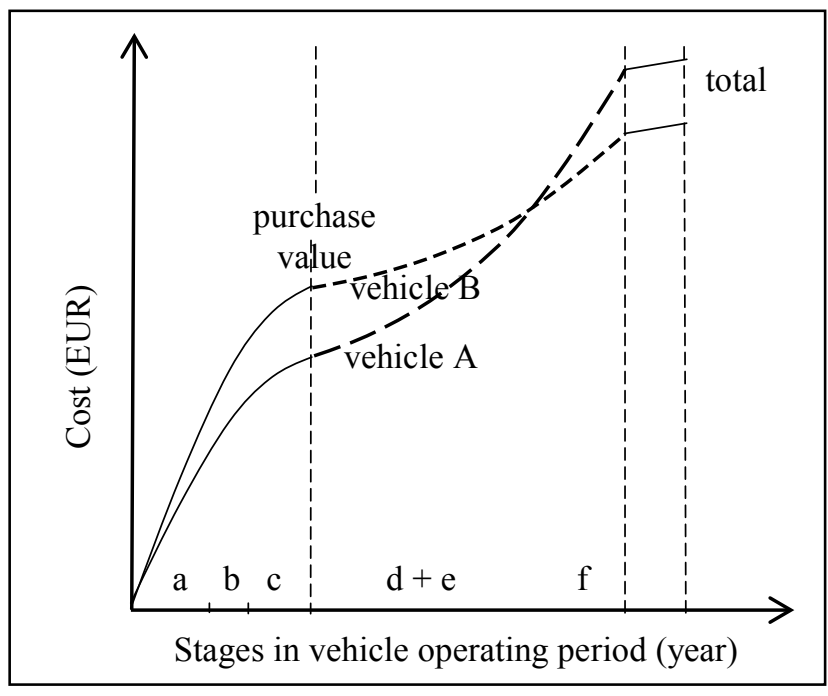

Figure 1 Cost in vehicle operating period

Overall understanding and proper evaluation of maintenance cost and cost of direct use is important when acquiring new vehicles for the purpose of military logistics. The basis for purchase must be the purchase value with the addition of proper and clear evaluation of total cost of use during the vehicle's entire operating period. An overview of the state in the field of acquiring military equipment shows that generalised models adapted to conditions of commercial vehicle exploitation are used for evaluating the total cost of vehicle use in the stage of purchasing new vehicles for military logistics. These generalised models do not include specific 
demands determined by the configuration of military vehicles as well as conditions and ways of using vehicles in military logistics. That is why the total cost of use in the military vehicle's operating period is treated in the context of cost compromises.

The cost of the work equipment's entire operating period is the sum of all cost components within a service cycle. The total cost of use of vehicles in military logistics (cost of maintenance and direct use) calculated on the basis of manufacturers recommendations is usually insufficient and incomplete and it basically shows a significantly smaller extent of both preventive and remedial maintenance as well as minimal cost of direct use. The cost often excludes or scales down specific maintenance operation, both in the material extent and the amount of expenses, because the calculations are made on the basis of commercial vehicles. This quite often causes disproportionately high differences between the information of individual vehicle manufacturers for more or less equivalent vehicles because they start on a different basis and consider different boundary conditions.

It must be stated that the information given by the manufacturers is taken into account when purchasing new vehicles and offers are evaluated, as well as during the follow-up stages such as planning maintenance i.e. planning stock of replacement parts, developing technological procedures, defining time norms etc. which in practice often causes significant discrepancies between the state presented at the time of vehicle purchase and the actual state noted during vehicle exploitation. These discrepancies are even more disturbing and evident when planning use and maintenance of vehicles in military operations and peacekeeping missions abroad, especially in cases when a military unit must remain completely self-sufficient i.e. without requiring external support, either military or civilian.

\section{Vehicle maintenance in military logistics}

Military vehicles differ from ordinary (commercial) vehicles used in road traffic in technical characteristics, basic construction and performance, as well as system construction and performance, links and components built into vehicles. There are also differences in vehicle preparation procedures prior to use, conditions, purpose and ways of using the vehicles, and vehicle maintenance processes and procedures. The latter also demands a different approach to handling and evaluating the cost of maintenance and direct use during the operating period if compared to procedures used for evaluating the cost of vehicles used in road traffic.

NATO Member States perform maintenance of military vehicles in a manner where the maintenance is divided in several levels according to the extent and complexity of tasks. Maintenance is regulated with cover documents called the Allied Joint Logistic Doctrine [1, 2], which serves as a basis for documents defining organisation and processes of maintenance activities (Logistics Handbook [3], Standardization Agreement [4], Administrative Publication AAP-20 [5], etc.). Technical equipment maintenance levels in military logistics are presented in Tab. 1.
Table 1 Technical equipment maintenance levels

\begin{tabular}{|l|l|}
\hline Slovenian Armed Forces & \multicolumn{1}{|c|}{ NATO } \\
\hline Basic maintenance & Operator level \\
\hline I. Level & Organizational level or unit level \\
\hline II. Level & Direct support level \\
\hline III. Level & General support level \\
\hline
\end{tabular}

Long-term goal of optimizing combat and noncombat vehicle maintenance must be directed towards achieving maximum vehicle reliability and readiness at minimum cost, regardless of performing maintenance using own personnel and capacities or outside contractors. Set goals can be achieved with efficient use of resources, methodologies and modern technologies. We also need to consider the fact that military vehicle maintenance must not be regarded solely from the point of view of costs because proper and timely maintenance influences reliability and readiness of units and commands using these vehicles, which is more important than the cost itself in most cases, especially in performing missions in international military operations and peacekeeping missions.

\section{Analytical models of evaluating cost of vehicles use in military logistics}

There are no exact analytical models for evaluating cost of maintenance and direct use of military vehicles within NATO. When calculating costs during the operating period, individual member states use models which are not consistent and are prepared by individual manufacturers of commercial vehicles. If different base (initial) and boundary conditions are taken into account, results are not comparable and can only be used as a reference point for vehicle maintenance (servicing) with out-sourcing, but they certainly do not include overall maintenance and related expenses. A common management policy called System Life Cycle Management (SLCM) [6, 7] was introduced in NATO and its basic purpose is to achieve a comprehensive approach to providing defence capabilities.

An administrative publication called the Allied Administrative Publication - 48 (AAP-48) [8, 9] was published for the purpose of serving as guidance or guideline for implementing system life cycle management policies. The AAP-48 guidance defines and describes the common framework of system life cycle management of all NATO defence capabilities. Final operative capabilities of units and commands are assured by completing or upgrading the AAP-48 guidance with other common system documents i.e. instructions regarding management, quality assurance and system engineering. The concept of system life cycle management in accordance with the AAP-48 guidance is shown in Fig. 2. The AAP-48 document serves as guidance for developing, modelling and implementation of process models of system life cycle management. The guidance within life cycle stages covers individual processes: contract processes, project processes, technical processes and adaptation processes. The AAP-48 guidance does not cover or describe cost processes and it consequently does not cover models for monitoring, managing and evaluating costs. The extent, diversity and specifics of 
military equipment, especially technical equipment, make it impossible to establish a universal or unified model for cost evaluation that would include all assets. Therefore, the AAP-48 guidance is insufficient in itself regarding costs during the equipment life cycle and must be upgraded or models treating maintenance costs and cost of direct use during the system life cycle must be added.

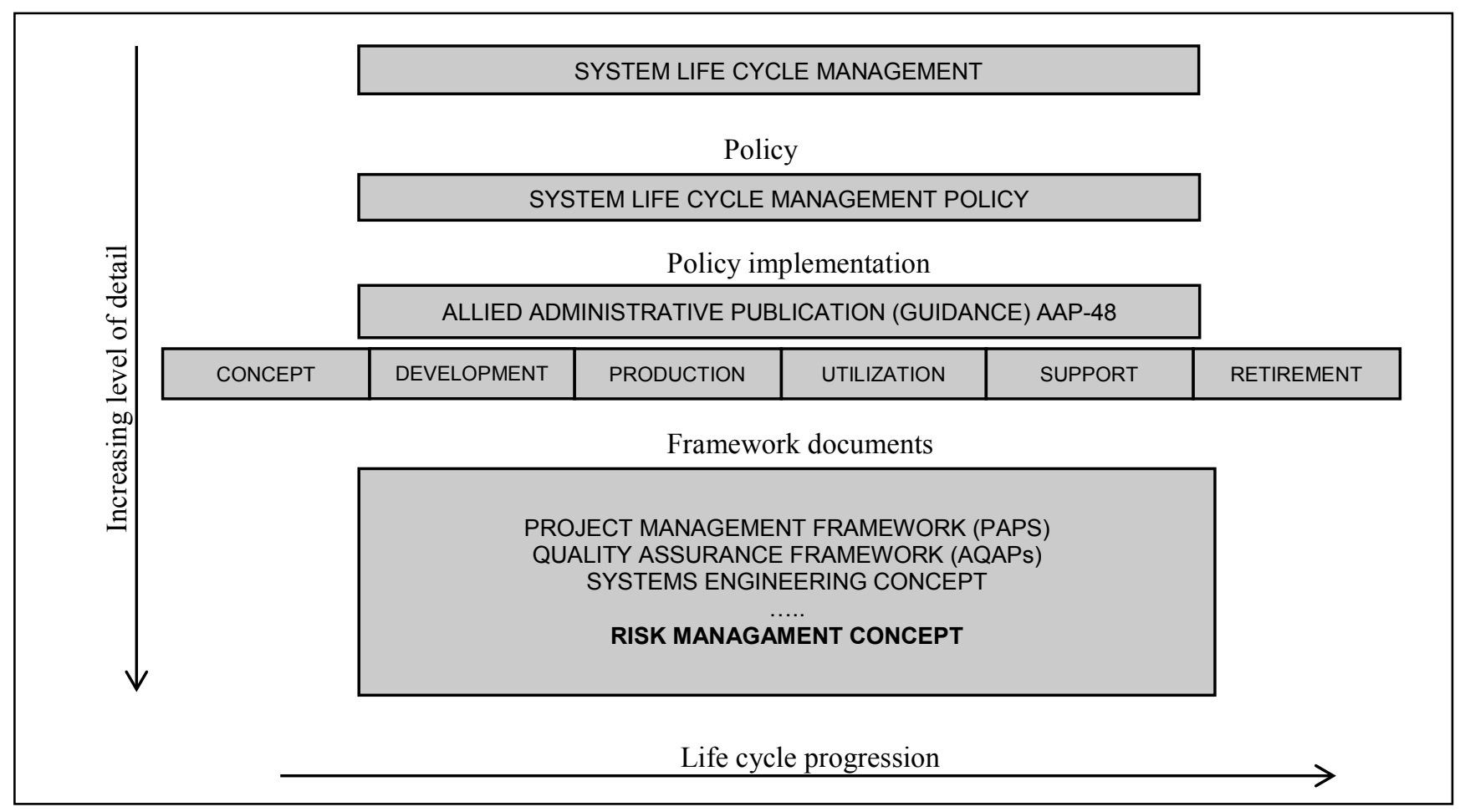

Figure 2 System life cycle management concept [11]

\subsection{Vehicle maintenance cost in military logistics}

Based on the analysis of technological maintenance procedures, it is concluded that vehicle maintenance cost in military logistics can be essentially summed up in three primary groups: the cost of preventive maintenance, the cost of remedial maintenance and fixed maintenance costs. When purchasing new military vehicles and introducing them into operative use, the evaluation of fixed maintenance costs consists of documentation, identification and codification costs, cost of training and acquiring special tools and measuring and testing equipment. Cost evaluation of preventive and remedial vehicle maintenance in military logistics includes the estimated direct cost i.e. workforce and material cost, cost of outsourcing and indirect cost.

The primary task of evaluating maintenance cost is to provide as accurate and complete information regarding individual maintenance procedure as possible. In order to do that, the extent, type, time norms and conditions of the procedure must be known. The accuracy of the estimate depends solely on clearly planned and defined tasks or technological procedures. An important factor with cost evaluation is also the assessment whether certain maintenance procedures are carried out internally or with outside partners, which can have a long-term effect on the overall estimate of cost, both in negative and positive sense. Lowering maintenance cost is directly connected with extending the Mean Time Between Failure (MTBF) and reducing the Mean Time to Repair (MTTR).

\subsection{Cost of direct vehicle use in military logistics}

For a simplified approach, the cost of direct vehicle use in military logistics is logically divided into three basic groups: variable expenses, fixed (administrative) cost and cost of vehicle decommission.

Variable expenses of direct vehicle use in military logistics represent the cost of fuel consumption. Fixed (administrative) cost includes the cost of vehicle implementation into operative use, the cost of insurance, the annual fee for the use of motor vehicles in road traffic, the cost of technical inspection, mandatory periodic inspections (tachograph calibration, speed limiter calibration, ADR vehicle check etc.), vehicle registration, motorway tolls and charges for use of infrastructure (bridges, tunnels, ferries etc.).

The cost of vehicle decommission is a one-time expense during the vehicle's operating period. It is treated separately due to its specifics. These expenses arise when the vehicle is no longer suitable for further use due to mechanical failure or damage, wear and tear or inconsistency with regulations.

\section{Forming an analytical model for evaluating the overall cost of direct vehicle use in military logistics}

When we form an analytical model for evaluating overall cost of use (cost of maintenance and direct use), it is important to reach the best possible decision according to available information to evaluate expenses in advance. The purpose of cost evaluation is not to have a precise and consistent estimate, but to gather and analyse 
sufficient and detailed information. The latter can later be used to help reach decisions in the stage of purchasing new vehicles and also in vehicle maintenance and restoration processes.

Several documents are available that deal with expenses during the operating period (life cycle) based on Cost Breakdown Structure (CBS) [10, 11, 12, 13, 14]. The CBS model treats costs according to individual stages in the life cycle i.e. operating period and with regard to anticipated processes and activities, which are expected within individual stages. The NATO AAP-48 document provides guidelines for establishing models for system life cycle management, whereas the CBS model basically presents a model of defining expenses that occur during the entire operating period of assets or systems. But the CBS model does not deal with cost on an analytical level and it is only used as an instrument for: defining expense lists during the operating period, defining the extent of expenses during the operation period, defining cost relation according to individual stages of the operating period and determining the level of individual expenses or expense groups.

The process of modelling and simulating the system of overall cost of vehicle use in military logistics throughout the entire operating period (life cycle) consists of steps defined in Tab. 2.

Table 2 Steps in modelling and simulation process

\begin{tabular}{|c|l|l|}
\hline No. & \multicolumn{1}{|c|}{ Step } & \multicolumn{1}{|c|}{ Description } \\
\hline 1 & System definition (NATO SLCM Policy) & Life cycle - military vehicle operating period \\
\hline 2 & System management (NATO AAP-48) & Model of system life cycle management (stages, processes) \\
\hline 3 & Real system definition (NATO CBS) & Life cycle (operating period) cost of military vehicles \\
\hline 4 & Forming an analytical model & Selection of variables, modelling method, determining relations \\
\hline 5 & Formal model & Modelling, building an analytical (mathematical) model \\
\hline 6 & Programming & Process of remodelling mathematical model into formal language \\
\hline 7 & Program & Mathematical model in formal (programming) language \\
\hline 8 & Calculations and simulations & Calculations, comparisons \\
\hline 9 & Model analysis & Following guidelines, test examples, real data \\
\hline 10 & Model corrections & Simulation development, final model construction \\
\hline
\end{tabular}

\subsection{Initial (entry) criteria}

Initial or entry criteria (conditions) for designing an analytical model of evaluating total cost of vehicle use in military logistics throughout its operating period (life cycle) are of external and internal character. Basic information used to form external initial criteria includes technical data, commercial (market or sales) data and vehicle manufacturer's documentation. Basic information used to form internal initial criteria includes information and documents provided by Slovenian Armed Forces which contain descriptions of maintenance processes and vehicle use within the stages of manufacture (production), use (utilization), maintenance (support) and decommission (out of use) during the operating period or life cycle of vehicles in military logistics.

\subsection{Boundary criteria}

Boundary criteria (conditions) include variables (quotients) that define the cost of preventive maintenance, the cost of remedial maintenance, fixed maintenance cost, variable cost of use, fixed cost of use and decommission cost. The value of variables (quotients) must be defined on a case-by-case basis depending on the type of conditions and manner the vehicles in military logistics are being used in. It is reasonable to consider the documents entitled Military Equipment Useful Life Study - Phase II [15] and Impact of Military Operational Tempo on Military Equipment Useful Life and Associated Reconstitution and Maintenance Costs [16]. These documents present the basis for determining the value of variables (quotients) which define the cost of direct vehicle use in military logistics.

\subsection{Analytical model of evaluating total cost of vehicle use in military logistics}

We defined initial (entry) and boundary criteria and calculation processes to develop an analytical (formal) model for evaluating the total cost of use (maintenance and direct use) of vehicles in military logistics during their operating period (life cycle).

Initial (entry) criteria:

$D 1, N 1, M 1, K 1$;

D2, N2, M2, K2, MTBF, MTTR;

$F V$;

$B_{\text {povpr }}, G_{\text {povpr }}, S K M$

$F U$ and

IU.

Boundary criteria:

$k_{I D, i}, k_{I M, i}, f_{1, i}, m(i=1, \ldots, m)$;

$k_{2 D, j}, k_{2 M, j}, f_{2, j}, n(j=1, \ldots, n)$;

$k_{3 F, k}, f_{3, k}, p(k=1, \ldots, p)$;

$k_{4 V}, f_{4}$;

$k_{5 F, u}, f_{5, u}, q(u=1, \ldots, q)$ and

$k_{6 I, v}, r(v=1, \ldots, r)$.

Calculation - maintenance cost - VDT:

$$
\begin{aligned}
& V D T=V 1+V 2+V 3(\mathrm{EUR}) \\
& V D T=\sum_{i=1}^{m}\left(\left(D 1_{i, \text { predp }} \cdot k_{1 D, i}+M 1_{i, \text { predp }} \cdot k_{1 M, i}\right) \cdot f_{1, i}\right) \\
&+\sum_{j=1}^{n}\left(\left(D 2_{j, \text { predp }} \cdot k_{2 D, j}+M 2_{j, \text { predp }} \cdot k_{2 M, j}\right) \cdot f_{2, j}\right) \\
&+\sum_{k=1}^{p}\left(\left(F V_{k, \text { predp }} \cdot k_{3 F, k}\right) \cdot f_{3, k}\right)
\end{aligned}
$$




$$
\begin{aligned}
& \text { Calculation }- \text { cost of use }-U D T: \\
& U D T=U 1+U 2+U 3(\text { EUR }) \\
& \begin{array}{l}
U D T=\left(\left(B_{\text {predp }} \cdot k_{4 V} \cdot f_{4} \cdot G_{\text {povpr }} \cdot S K M\right) \cdot 100\right) \\
+\sum_{u=1}^{q}\left(\left(F U_{u, \text { predp }} \cdot k_{5 F, u}\right) \cdot f_{5, u}\right) \\
\quad+\sum_{v=1}^{r}\left(\left(I U_{v, \text { predp }} \cdot k_{6 I, v}\right)\right) \quad(\text { EUR })
\end{array}
\end{aligned}
$$

Calculation - total cost of use $-S D T$ :

$S D T=V D T+U D T(\mathrm{EUR})$

Calculation - average total cost of use - PSDT:

$$
P S D T=\frac{S D T}{S K M}\left(\frac{\mathrm{EUR}}{\mathrm{km}}\right)
$$

Result: The final result gives the value of the average total cost of use i.e. maintenance cost and the cost of direct vehicle use in military logistics throughout its entire operating period, expressed as EUR/km.

The following symbols were used in the expressions determining the analytical model:

$D 1_{i} \quad$ labour cost of a single preventive maintenance procedure;

$N 1_{i} \quad$ number of hours used for a single preventive maintenance procedure;

$M 1_{i} \quad$ cost of material used in a single preventive maintenance procedure;

$K 1_{i} \quad$ amount of material used in a single preventive maintenance procedure;

$D 2_{j} \quad$ labour cost of a single remedial maintenance procedure;

$N 2{ }_{j} \quad$ number of hours used for a single remedial maintenance procedure;

$M 2_{j} \quad$ cost of material used in a single remedial maintenance procedure;

$K 2{ }_{j} \quad$ amount of material used in a single remedial;

$M T B F \quad$ Mean Time Between Failure;

MTTR Mean Time to Repair;

$F V_{k} \quad$ fixed maintenance cost;

$B_{\text {avg }} \quad$ average fuel consumption in $1 / \mathrm{km}$;

$G_{\text {avg }} \quad$ average fuel value (price);

SKM total mileage during the vehicle's life cycle;

$F U_{u} \quad$ single value of fixed cost of use;

$I U_{v} \quad$ cost of single decommission;

$k_{1 D, i}$ labour cost quotient of a preventive maintenance procedure;

$k_{1 M, i}$ material cost quotient of a preventive maintenance procedure;

$f_{l, i} \quad$ frequency coefficient of a single preventive maintenance procedure;

$i \quad$ single preventive maintenance procedure;

$m$ total number of different preventive maintenance procedures;

$k_{2 D, j}$ labour cost coefficient of a remedial maintenance procedure;

$k_{2 M, j}$ material cost coefficient of a remedial maintenance procedure; $f_{2, j} \quad$ frequency coefficient of a single remedial maintenance procedure;

$j \quad$ single remedial maintenance procedure;

$n$ total number of all different remedial maintenance procedures;

$k_{3 F, k} \quad$ coefficient of fixed maintenance costs;

$f_{3, k} \quad$ frequency coefficient of fixed maintenance costs appearance;

$k \quad$ single fixed maintenance cost;

$p \quad$ total number of all different fixed maintenance costs;

$k_{4 V} \quad$ coefficient of variable costs of use;

$f_{4} \quad$ corrective coefficient of fuel consumption;

$k_{5 F, u} \quad$ quotient of fixed cost of use;

$f_{5, u}$ frequency coefficient of fixed cost of use appearance;

$u \quad$ single fixed cost of use;

$q \quad$ total number of all different fixed costs of use;

$k_{6 I, v} \quad$ quotient of decommission cost;

$v \quad$ single decommission cost;

$r$ total number of all different decommission costs;

VDT maintenance cost during a life cycle;

$V 1$ total cost of preventive maintenance;

V2 total cost of remedial maintenance;

V3 total fixed maintenance cost;

$D 1_{i, \text { est }}$ estimated labour cost of a single preventive maintenance procedure;

$M 1_{i, \text { est }}$ estimated material cost of a single preventive maintenance procedure;

$D 2_{j, \text { est }}$ estimated labour cost of a single remedial maintenance procedure;

$M 2_{j, \text { est }}$ estimated material cost of a single remedial maintenance procedure;

$F V_{k, \text { est }}$ estimated fixed maintenance cost;

UDT cost of use during a life cycle;

U1 total variable cost of use;

U2 total fixed cost of use;

U3 total decommission cost;

$B_{\text {est }} \quad$ estimated average fuel consumption;

$G_{\text {avg }} \quad$ average fuel value (price);

$F U_{u, e s t}$ estimated fixed cost of use;

$I U_{v, \text { est }}$ estimated decommission cost;

SDT total life cycle cost in EUR and

PSDT average total cost of use.

It must be pointed out that the entire process of life cycle cost management is iterative. It consists of a series of variables and co-dependencies, wherein their mutual.

\subsection{Upgrading the NATO AAP-48 document}

The analytical model of evaluating the overall cost of military vehicle use in their operating period (life cycle) presents a supplement or upgrade of the NATO AAP-48 document. By defining initial (entry) and boundary criteria relating to processes and technological procedures of military vehicle maintenance and initial (entry) and boundary conditions relating to conditions of use or exploitation of military vehicles, the conditions are given for developing an analytical model for evaluating total cost of use (cost of maintenance and direct use) of vehicles in military logistics throughout their entire 
operating period (life cycle) i.e. from the point of purchase and implementation into operative use to decommissioning.

The developed analytical model presents an upgrade of the AAP-48 document, but only regarding military vehicles (combat and non-combat) as one of the groups of military equipment. There is a possibility of developing similar analytical models for other groups of military equipment, e.g. armaments and weapons systems, combat engineer equipment, electrical power equipment, quartermaster equipment, communications equipment, protection equipment etc.

\section{Example of suggested analytical model use}

The proposed analytical model enables: predicting overall costs of vehicle use in the purchasing stage (with acceptable deviations), analysing total cost of vehicle use throughout the entire operating period, a cost comparison between similar military vehicles of different manufacturers and evaluation of optimal vehicle operating period in military logistics. The proposed analytical model was used on an example of calculating vehicle cost of use in military logistics. To test the suitability of the model, a $6 \times 6$ medium tactical vehicle with a load capacity of 10 tons was selected. It was equipped and prepared for the most demanding field conditions. The selected vehicle presents one of the key logistical capabilities on a tactical level in all armed forces. It must be pointed out that there are several manufacturers of this type of vehicle, both in Europe and worldwide.

\subsection{Calculation analysis}

The results of the calculation are shown in Tab. 3 . The analysis shows that the remedial maintenance costs take up the larger part of the maintenance cost and the variable costs i.e. the fuel consumption costs present most of the costs of direct use.

Table 3 Cost calculation results for the selected vehicle

\begin{tabular}{|c|c|c|c|c|}
\hline No. & Description & Value in EUR $/ \mathrm{km}$ & Partial share in $\%$ & Overall share in $\%$ \\
\hline \multicolumn{5}{|c|}{1 Maintenance costs } \\
\hline 1.1 & Preventive maintenance & 0,15 & 14,7 & 7,6 \\
\hline 1.2 & Remedial maintenance & 0,72 & 70,6 & 36,6 \\
\hline \multirow[t]{2}{*}{1.3} & Fixed maintenance cost & 0,15 & 14,7 & 7,6 \\
\hline & Total maintenance costs & 1,02 & 100 & \\
\hline \multicolumn{5}{|c|}{2 Direct use cost } \\
\hline 2.1 & Variable cost of use & 0,61 & 64,2 & 31,0 \\
\hline 2.2 & Fixed cost of use & 0,31 & 32,6 & 15,7 \\
\hline \multirow[t]{2}{*}{2.3} & Decommission cost & 0,03 & 3,2 & 1,5 \\
\hline & Total direct use cost & 0,95 & 100 & \\
\hline \multicolumn{5}{|c|}{3 Total cost of use } \\
\hline 3.1 & Total cost & 1,97 & & 100 \\
\hline
\end{tabular}

Based on the analytical model, the overall cost of use for the selected vehicle is $1,97 \mathrm{EUR} / \mathrm{km}$. Within a public call for tenders for the purchase of new medium tactical vehicle for the needs of Slovenian Armed Forces, two binding tenders of globally renowned manufacturers of commercial and military vehicles were received.

The cost of use presented in the first tender amounts to $0,64 \mathrm{EUR} / \mathrm{km}$, and the cost of use in the second tender is $1,08 \mathrm{EUR} / \mathrm{km}$. The discrepancy between the two tenders for equivalent vehicles and with the same reference level is as high as $0,44 \mathrm{EUR} / \mathrm{km}$ or $40,7 \%$. But it must be pointed out that the cost of vehicle use was one of the selection criteria causing the vehicle with lower cost to score much higher. The cost of use was definitely not presented properly because it was not treated in the same context i.e. with the same analytical model for both vehicles.
Later the cost of use was compared based on the criteria of vehicle use in road traffic [17]. The basis for cost calculation was taken from local traffic in two variations - with and without labour cost (the driver's salary). On this basis, the cost of use amounts to 1,15 $\mathrm{EUR} / \mathrm{km}$ or $1,37 \mathrm{EUR} / \mathrm{km}$ which is significantly higher than the cost presented in the tenders for new medium tactical vehicles and conditions of use in military logistics.

To sum up, the cost of use stated in the tenders for the purchase of new tactical vehicles for the Slovenian Armed Forces is not completely accurate. Tougher conditions and manner of use, as well as significantly higher demands regarding military vehicle maintenance, by no means justify lower costs of use, as they exist in local road traffic transport. Tab. 4 shows different results of calculated cost of use for the selected tactical military vehicle.

Table 4 Calculation result analysis of the sample vehicle use

\begin{tabular}{|c|l|c|c|}
\hline No. & \multicolumn{1}{|c|}{ Description } & Value in EUR/km & Share in \% \\
\hline 1 & Vehicle 1 - tender amount & 32,49 & 1,04 \\
\hline 2 & Vehicle 2 - tender amount & 54,82 & 1,15 \\
\hline 3 & Calculation - local road traffic (no labour cost) & 1,37 & 58,38 \\
\hline 4 & Calculation - local road traffic (with labour cost) & 69,54 & 1,97 \\
\hline 5 & Calculation based on the analytical model & 100 & \\
\hline
\end{tabular}

If the calculated costs are compared with costs provided in the manufacturers' tenders, the cost from the first tender is only $32,49 \%$ and the second tender only $54,82 \%$ of the calculated value. Another proof of the 
presented data being unrealistic i.e. minimized with the purpose of achieving a higher score is the fact that the cost in the tender is also lower than the cost calculated based on use in local road traffic or transport. The cost based on the calculation of transport cost in local road traffic, not including labour cost, amounts to 58,38\% of cost calculated using the model and $69,54 \%$ if the cost of labour is added. The difference in the amount of cost is completely acceptable because transport cost calculations for local road traffic are based on completely different conditions and manner of vehicle use as it is for the use of cargo vehicles in military logistics.

Total cost based on the model amounts to 1,97 EUR $/ \mathrm{km}$. Considering the expected vehicle operating period (life cycle) of 20 years with $10000 \mathrm{~km} / \mathrm{year}$, the total cost of use over the entire operating period (life cycle) of the selected vehicle is 394000 EUR. The ratio between the vehicle purchase value and total cost of use over the operating period is $47 \%$ or $53 \%$ of the total value.

Based on these findings, it is completely justifiable to establish an analytical model for cost calculation of vehicle use in military logistics. The presented example proves that the results provided by the manufacturers or their authorised representatives are inaccurate and unrealistic because they do not even reach the cost of local goods transport in road traffic, which proves beyond doubt the irregularities and inconsistencies of cost evaluation of vehicle use in military logistics. The use of own special model, which takes into account all realistic initial (entry) and boundary conditions, is therefore more than justifiable.

\section{Conclusion}

There are currently no versions of an analytical model in the field of military logistics that would fully meet the demands for evaluating overall cost of use (cost of maintenance and direct use) of military vehicles in military logistics. Certain technological solutions and generalised analytical models are available but they are entirely adapted to commercial vehicles, with completely different conditions and manner of use and different technological approaches in performing maintenance procedures.

The calculations prepared on the basis of manufacturers' recommendations i.e. their generalised analytical models are usually adapted to present the results with the best possible outcome and the best vehicle cost efficiency. But on the other hand, the calculations made only on the basis of past experience are often insufficient and include mainly flat-rate amounts because they do not take into account the actual conditions, mostly due to lack of complete and consistent data. The aforementioned reasons were grounds enough to develop and implement an analytical model for evaluating the cost of maintenance and direct use of vehicles in military logistics.

\subsection{Limitations in the use of the model}

The practical application of the analytical model for evaluation of total cost of use (cost of maintenance and direct use) is subject to certain risks which could present several problems in further implementation of the model. The risks result from the following limitations:

- Undefined or incomplete procedures and data gathering methods;

- Outdated or incompatible software in the field of gathering, storing and evaluating data;

- Unavailability or inaccessibility of internal technical-technological and work documentation and related information and

- Unavailability or inaccessibility of manufacturers' original documentation and data applying to maintenance costs and the cost of direct vehicle use in military logistics.

\subsection{Possible further development of the model}

By supporting the analytical model, it will later on be possible to anticipate the necessary technological maintenance procedures or changes in existing procedures which can affect the condition of the vehicles and, consequently, their reliability during use. Supporting the analytical model will indirectly affect achieving a larger (maximum) availability of military vehicles at the lowest possible (minimum) cost, regardless of where maintenance is carried out (internally or out-sourcing). The analytical model will thus have an indirect effect on the rationalisation of maintenance.

The results gathered with the implementation of the analytical model for evaluation of total cost of vehicle use in military logistics also further enable the following:

- Preparation of accurate plans of financing maintenance activities;

- Acquiring accurate and complete information on maintenance procedures;

- Control of additional (unforeseen) maintenance cost and cost of direct use;

- Recognition, comparison and evaluation of various sources and cost factors;

- Evaluation of different cost influences;

- Comparison of different cost dynamics;

- Classification and quantification of various costs;

- Increase in Mean Time Between Failure (shortened MTBF);

- $\quad$ Decrease in Mean Time to Repair (shortened MTTR) and

- Optimisation (lowering) of total cost of vehicle use in military logistics over the entire operating period.

\section{References}

[1] Allied Joint Logistic Doctrine AJP-4(A). NATO Standardization Agency (NSA), December 2003.

[2] Allied Joint Logistic Doctrine. AJP-4(B). NATO Standardization Agency (NSA), 2007.

[3] NATO Logistics Handbook. NATO HQ, Brussels, April 2007.

[4] Standardization Agreement STANAG 4728. System Life Cycle Management. NATO Standardization, November 2012.

[5] Phased Armaments Programming System Allied Administrative Publication. AAP-20. NATO International Staff, February 2010. 
[6] NATO Policy for System Life Cycle Management. NATO North Atlantic Council, 16 January 2006.

[7] NATO Policy on an Integrated Systems Approach to Quality Trough the Life Cycle. NATO International Staff, November 2009.

[8] NATO System Life Cycle Stages and Processes. Allied Administrative Publication. AAP-48. NATO Standardization Agency, February 2007.

[9] NATO System Life Cycle Processes. Allied Administrative Publication. AAP-48. NATO Standardization Agency, March 2013.

[10] Cost Structure and Life Cycle Costs for Military Systems. NATO Research and Technology Organization, September 2003.

[11] Methods and Models for Life Cycle Costing. NATO Research and Technology Organization, June 2007.

[12] Code of Practice for Life Cycle Costing. NATO Research and Technology Organization, September 2009.

[13] The CNAD Life Cycle Management Group, AC/327. NATO Defence Investment, October 2008.

[14] Đorđević, M. S.; Zrnić, N. Đ.; Miličević, M. R.; Mišković, V. V. Information and Material Flow Modeling in System of Parts Regeneration in Multi-level Supply System. // Tehnički vjesnik - Technical Gazette. 20, 5(2013), pp. 861869.

[15] Military Equipment Useful Life Study - Phase II. Department of Defense USA, May 30, 2008.

[16] Impact of Military Operational Tempo on Military Equipment Useful Life and Associated Reconstruction and Maintenance Costs. Department of Defense USA, March 31, 2007.

[17] Hočevar, M. Kalkulacija stroškov kamionskega prometa. Ekonomska fakulteta, Ljubljana, 2008.

\section{Authors' addresses}

\section{Leon Grašič, Senior military specialist}

Ministry of Defence,

Slovenian Armed Forces,

Vojkova cesta 55, 1000 Ljubljana, Slovenia

E-mail: leon.grasic@mors.si

\section{Tone Lerher, Full professor}

University of Maribor,

Faculty of Logistics,

Mariborska cesta 7, 3000 Celje, Slovenia

E-mail: tone.lerher@um.si

\section{Bojan Rosi, Full professor}

University of Maribor,

Faculty of Logistics,

Mariborska cesta 7, 3000 Celje, Slovenia

E-mail: bojan.rosi@uni-mb.si 